\title{
球体高速衝突試験に基づく材料のひずみ速度依存性推定手法の開発
}

\author{
伊藤 潔洋*1，村松 寿和*2，荒井 正行*1

\section{Development of estimation method of strain rate dependency of materials based on a high- velocity impingement test with a solid sphere} \\ Kiyohiro ITO*1, Toshikazu MURAMATSU ${ }^{* 2}$ and Masayuki ARAI ${ }^{* 1}$ \\ ${ }^{* 1,{ }^{*} 2}$ Graduate School of Mechanical Engineering, Tokyo University of Science \\ 6-3-1 Niijuku, Katsushika-ku, Tokyo 125-8585, Japan
}

Received: 4 March 2020; Revised: 9 April 2020; Accepted: 27 May 2020

\begin{abstract}
Johnson-Cook (JC) flow stress model is widely used in computer aided engineering (CAE) for simulations of car crash and machining behaviors. The JC parameter $C$, which is a material constant in the model associated with strain rate dependency, is usually identified by a split-Hopkinson bar method. However, a huge equipment is required for this method to achieve an appropriate test condition. Therefore, the JC parameter $C$ is expected to be estimated by a simpler method. In this study, an estimation method of the JC parameter $C$ based on a high-velocity impingement test with a solid sphere, which is called EJCC, was developed. The fundamental equation in the EJCC was theoretically derived based on the energy conservation during impingement process, which was previously reported by our research group. Using the EJCC, the JC parameter $C$ can be easily estimated with a depth of indentation obtained by the impingement test and the other JC parameters identified by a quasi-static tensile test. The quasi-static tensile test, the high-velocity impingement test and a high-speed tensile test were conducted to identify the $\mathrm{JC}$ parameters $A, B, n$ and estimate the JC parameter $C$ on three ductile metallic materials. As a result, the JC parameter $C$ estimated by the EJCC was in good agreement with that obtained by the high-speed tensile test irrespective of materials and impingement velocities. Consequently, it was demonstrated that the EJCC can appropriately estimate the JC parameter $C$ on ductile metallic materials.
\end{abstract}

Keywords : High-velocity impingement, Indentation, Johnson-Cook model, Strain rate dependency, Finite element analysis

\section{1. 緒言}

自動車，航空機，機械加工などの様々な産業分野において，CAE（Computer aided engineering）解析が必要不可 久となっている．自動車メーカーでは，自動車の安全性を評価するために自動車の衝突試験を行っている．しか しながら，実車両を用いた衝突試験には多大なコストがかかるため，衝突試験前に CAE 解析により衝突シミュ レーションを行うことが主流となっている（小野他, 2016)。この手法では, 自動車を製造する必要がないため, 様々な条件下で容易に複数回の解析を行うことができる. また，機械加工メーカーでは，材料の切削加工シミュ レーションに対し CAE を適用し，最適な加工条件の選定が試みられている（Bäker，2015）。自動車の衝突におい

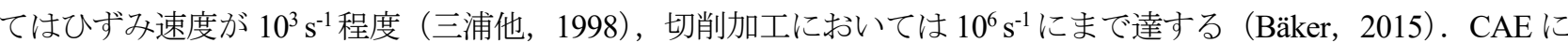

No.20-00060 [DOI:10.1299/transjsme.20-00060], J-STAGE Advance Publication date : 4 June, 2020

${ }^{* 1}$ 正員, 東京理科大学 工学部 機械工学科（广125-8585 東京都葛飾区新宿 6-3-1）

*2 東京理科大学 工学部 機械工学科

E-mail of corresponding author: kiyohiro@rs.tus.ac.jp 
より車体の変形や切削加工を精度よくシミュレーションするためには，高ひずみ速度での材料の変形特性の把握 も必要である.

一般的な金属材料の降伏応力はひずみ速度に依存することが知られる（谷村, 1990)。そのため，ひずみ速度依 存性を考慮した加工硬化モデルがいくつか提案されている．比較的よく用いられる加工硬化モデルとして， Cowper-Symonds モデル（Cowper and Symonds, 1957）やJohnson-Cook（JC）モデル（Johnson and Cook, 1983）など がある．JC モデルは次式のように表現される。

$$
\sigma_{y}=\left(A+B \bar{\varepsilon}_{p}^{n}\right)\left(1+C \ln \frac{\dot{\dot{\varepsilon}_{p}}}{\dot{\varepsilon}_{0}}\right)\left\{1-\left(\frac{T-T_{\mathrm{ref}}}{T_{m}-T_{\mathrm{ref}}}\right)^{m}\right\}
$$

ここで， $\sigma_{y}$ は降伏応力であり， $A, B, C, m$ および $n$ は JCパラメータと呼ばれる材料定数である. また, $T, T_{\mathrm{ref}}$ および $T_{m}$ は，基材の温度，参照温度，基材の融点， $\bar{\varepsilon}_{p}$ おび㐫は相当塑性ひずみおよび相当塑性ひずみ速度， $\dot{\varepsilon}_{0}$ は参照ひずみ速度である. 式中の右辺第 1 項は塑性変形による加工硬化, 第 2 項はひずみ速度依存性, 第 3 項は 温度依存性をそれぞれ表している。これらのモデルを CAE 解析などに適用するためには，高ひずみ速度下での 材料試験を行い，式中の材料定数（JCパラメータC）を同定する必要がある.

高ひずみ速度下での材料の変形特性（降伏応力）を評価するために, ホプキンソン棒法, 検力ブロック法, 油 圧サーボ法などの試験法が主に用いられている.

ホプキンソン棒法では, 加速された衝撃棒を入力棒に衝突させることにより, 入力棒および出力棒の間に設置 された試験片に対して高ひずみ速度での変形を与えるものである（小川, 2002). $10^{2} \sim 10^{4} \mathrm{~s}^{-1}$ 程度のひずみ速度範 囲において，比較的大きいひずみまで変形特性を評価できる。しかしながら，ひずみ速度を一定に保つためには 試験片の長さに合わせて衝撃棒の形状を設定しなければならない，加えて，試験片に生じるひずみや荷重を直接 測定しているわけではないため, 試験片に作用する応力一ひずみ関係を適切に評価するには技術や経験を要する. また, 衝突により入力棒内に発生する応力波と試験片との接触面で生じる反射波が干渉すると, 適切に測定を行 うことができない. そのため, 入力棒および出力棒の長さが数 $\mathrm{m}$ オーダーとなり, 試験装置が大型化するなどの 課題がある.

検力ブロック法では，十分大きなベースブロックに検力用小突起（ロードセル）が設けてあり，小突起上に試 験片が設置される. 試験片には落鍾により衝撃荷重が負荷される（三村他, 1996）。その際, 応力波はベースブロ ック内で乱反射し減衰寸るため, ベースブロックから小突起部への反射波を微弱にできるというものである．し かしながら, 検力用小突起は繰返し使用することでその衝撃端に変形が生じること, より高ひずみ速度下での試 験のために検力用小突起の剛性を大きくするとロードセルとしての感度が低下寸ることなどの課題がある.

また, 油圧サーボ法では, 極短時間で目標速度に到達させるための加速機構を有する油圧サ一ボ式引張試験機 が用いられる（高木, 2011）。ひずみ速度 $500 \mathrm{~s}^{-1}$ 程度までの試験が行えるが，大荷重負荷時には目標ひずみ速度か ら実際のひずみ速度が大きく隇衰するなどの課題がある.

このように，これらのいずれの試験法においても大規模な装置を必要とすることや，試験片に作用する応力一 ひずみ関係を適切に評価する必要があるなどの課題を有する．このことから，より簡便な JC パラメータ $C$ の評 価手法の開発が求められている. そのため, 近年様々な手法が提案されている. Grazka らは, JCモデルにおける パラメータ $C$ を評価するため, テイラー試験を応用した評価手法を提案している (Grazka and Janiszewski, 2012). テイラー試験とは, 円柱形状の試験片を高速で剛体壁面に衝突させることにより, 試験前後の試験片形状からひ ずみや降伏応力などを測定する方法である，提案された評価手法では，衝突により変形した試験片の形状を測定 し, 有限要素解析（FEA）により変形形状が一致するように JC パラメータ $C$ を決定するというものである.ま た, Wahab らは，2つのローラーにて試験片をせん断するせん断加工試験を用いた手法を提案している（Wahab et

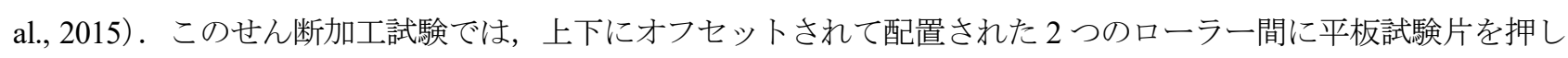
込んでいくことで，両ローラーのエッジにて試験片をせん断する. 本評価手法も同様にFEAを用いており，せん 断加工試験機のローラーにかかる加工力と FEA による加工力が一致するように JC パラメータ $C$ を決定する. Burley らは, 球体高速衝突試験に基づいた JC パラメータCの評価手法を提案している (Burley et al., 2018). 本 
手法は，球体高速衝突試験によって材料表面に形成される圧痕形状と，FEAにより得られる圧痕形状が最も一致 するようにパラメータ $C$ を決定するというものである. しかしながら，いずれの手法においても FEA による繰 り返し計算を必要と寸るため膨大な時間がかかるなどの課題があり，簡便な評価手法の確立が望まれる.

そこで，本研究では，FEA によらない JC パラメータ Cの簡便な評価手法として，球体高速衝突試験により得 られる圧痕深さに基づいた推定手法を提案する. 以降, 本手法を EJCC (Estimation method of Johnson-Cook parameter C) 法と呼ぶ. EJCC 法は, 当研究グループが提案している圧痕寸法予測理論に基づいている (Ito and Arai, 2020). 本理論は, 球体の衝突前後のエネルギー保存式に基づいて構築されている. エネルギー保存式には JC モデルが 組み込まれており, 適切な $\mathrm{JC}$ パラメータを導入することで基材表面に形成される圧痕寸法を精度よく予測可能 であることが確認されている. 一方, EJCC 法は, 準静的引張試験により得られる $C$ 以外の JC パラメータと球体 高速衝突試験により得られる圧痕深さをエネルギー保存式に導入することで, JC パラメータ $C$ を推定するもの である. 本手法では, JC パラメータ $C$ の推定に FEA を必要とせず， $C$ 以外の JC パラメータと圧痕深さをプログ ラムに入力寸るだけで推定結果が得られる点に特長がある.

本研究では, 純銅 (C1020), オーステナイト系ステンレス鋼（SUS304）および低炭素鋼（S15C）の3 種類の材 料に対して球体高速衝突試験を行い, EJCC 法による JC パラメータ Cの推定を試みた. また, 同材料に対して油 圧サーボ法による高速引張試験を行い, それにより得られた $C$ と本手法により推定された $C$ を比較することで本 手法の有効性を検証した.

\section{2. 球体高速衝突に基づくひずみ速度依存性推定手法}

\section{$2 \cdot 1$ 圧痕寸法予測理論およびEJCC 法の概要}

図 1 に, 圧痕寸法予測理論およびEJCC 法において想定された球体の平板基材上への衝突過程の模式図を示寸. 図のように, 半径 $R_{p}$, 質量 $m_{p}$ の球体が速度 $v_{i}$ で半無限平板基材上に垂直に衝突するものとする. 衝突過程にお いて, 基材表面は球体から一様な動的接触圧力 $p$ を受け，球体半径と同一の曲率を持つ圧痕が形成される. その 際，圧痕縁には盛り上がりが生じる. 衝突後, 球体は垂直に反発する. 球体の衝突前の初期運動エネルギーが基 材の塑性変形エネルギーと反発エネルギーに全て費やされるものと仮定すると, 衝突前後のエネルギー保存式は 以下のように表される.

$$
U_{\mathrm{imp}}-U_{\mathrm{reb}}-U_{\mathrm{def}}=0
$$

ただし， $U_{\mathrm{imp}}$ は球体の衝突前の初期運動エネルギー， $U_{\mathrm{reb}}$ は球体の反発エネルギー， $U_{\mathrm{def}}$ は基材の塑性変形エネル ギーである. 球体の初期運動エネルギー $U_{\mathrm{imp}}$ は以下のように定義される.

$$
U_{\mathrm{imp}}=\frac{1}{2} m_{p} v_{i}^{2}
$$

(a)

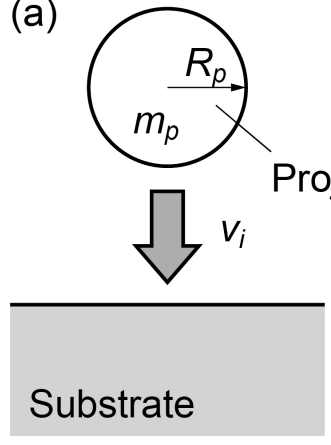

(b)

(c)

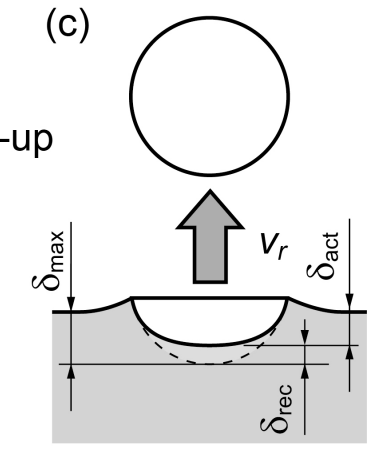

(c)

Pile-up

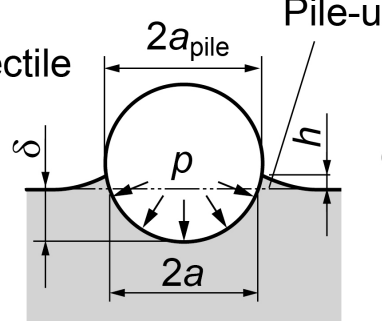

Fig. 1 Schematic illustration of impingement process of a solid sphere on a semi-infinite substrate. 
Johnson は, Hertz の接触理論に基づいて, 反発エネルギー $U_{\mathrm{reb}}$ を以下のように導出している (Johnson, 1985).

$$
U_{\mathrm{reb}}=\frac{3 \pi^{2} p^{2} a_{\mathrm{pile}}^{3}}{20 E^{*}}
$$

式中の $a_{\text {pile }}$ は盛り上がり部の圧痕半径である. また， $E^{*}$ は以下の式で表される等価縦弾性係数である.

$$
\frac{1}{E^{*}}=\frac{1-v_{p}^{2}}{E_{p}}+\frac{1-v_{t}^{2}}{E_{t}}
$$

ここで, $E$ は縦弾性係数, $v$ はポアソン比である. 下添字 $p$ および $t$ は, それぞれ球体および基材の物性值である ことを表す。

基材の塑性変形エネルギー $U_{\mathrm{def}}$ は, 以下の式によって求めることができる.

$$
U_{\mathrm{def}}=\int_{0}^{\delta_{\max }} P d \delta
$$

ここで， $\delta$ は元の基材表面に対する球体の侵入深さであり， $\delta_{\text {max }}$ は最大侵入深さである．また， $P$ は衝突中に基材 表面が球体から受ける衝突荷重であり，動的接触圧力 $p$ を用いて以下のように表される.

$$
P=p \cdot \pi a_{\mathrm{pile}}^{2}
$$

したがって，基材の塑性変形エネルギー $U_{\mathrm{def}}$ は,

$$
U_{\mathrm{def}}=\int_{0}^{\delta_{\mathrm{max}}} p \cdot \pi a_{\mathrm{pile}}^{2} d \delta
$$

によって求められる，式（3），(4）および（8）を式（2）に代入すると，衝突前後のエネルギー保存式は，

$$
\frac{1}{2} m_{p} v_{i}^{2}-\frac{3 \pi^{2} p^{2} a_{\mathrm{pile}}^{3}}{20 E^{*}}-\int_{0}^{\delta_{\max }} p \cdot \pi a_{\mathrm{pile}}^{2} d \delta=0
$$

となる．式（9）が EJCC 法における基礎式となる.

式（9）を解くためには, 動的接触圧力 $p$ および盛り上がり部半径 $a_{\text {pile }}$ を求める必要がある. 圧痕寸法予測理論 では，図 2 に示寸キャビティモデルに基づいて動的接触圧力 $p$ を定式化している. 図のように，球体の半無限平 板基材上への衝突問題を, 無限弹塑性体中に存在する 1 つのキャビティが内圧 $p$ を受けて膨張する問題に置き換 える. なお，キャビティ中心を原点とする球座標系を設定し，半径方向の座標を $r$ とする．ここで，キャビティ の体積が圧痕の体積の 2 倍に等しいと仮定すると,

$$
\frac{4 \pi R_{\mathrm{cav}}^{3}}{3}=2 \cdot \frac{\pi \delta\left(3 R_{p} \delta-\delta^{2}\right)}{3}
$$

したがって, キャビティ半径 $R_{\mathrm{cav}}$ は, 


$$
R_{\mathrm{cav}}=\left\{\frac{3}{2}\left(R_{p} \delta^{2}-\frac{1}{3} \delta^{3}\right)\right\}^{\frac{1}{3}}
$$

と表される．またキャビティの周囲には，r<cの範囲において球款状に塑性域が形成されており，その周りの $r$ $>c$ では弾性域となっている。 ここで， $c$ は塑性域寸法である.

Hill により, 準静的なキャビティの膨張問題における内圧 $p$ は以下の式によって求まることが明らかにされて いる (Hill, 1950).

$$
p=\frac{2}{3} \sigma_{E}+2 \int_{R_{\text {cav }}}^{c} \frac{\sigma_{y}}{r} d r
$$

ここで， $\sigma_{E}$ は弾性域における初期降伏応力， $\sigma_{y}$ は塑性域における降伏応力である. 準静的な球圧子の押込み試験 において，押込み圧力 $p$ はおおよそ降伏応力の 3 倍になることが知られている（Tabor, 1951）。このことから，基 材を弾完全塑性体と仮定した場合, 以下の式が成り立つ.

$$
3 \sigma_{E}=\frac{2}{3} \sigma_{E}+2 \int_{R_{\text {cav }}}^{c} \frac{\sigma_{E}}{r} d r
$$

式（13）を解くことにより，塑性域寸法 $c$ は,

$$
\frac{c}{R_{\text {cav }}}=e^{\frac{7}{6}}
$$

と表すことができる.

Hopkins は，Hill により提案されたキャビティモデルを動的なキャビティの膨張問題に拡張している. この場 合，内圧 $p$ は以下の式によって求まることが明らかにされている（Hopkins, 1960）.

$$
p=\frac{2}{3} \sigma_{E}+2 \int_{R_{\text {cav }}}^{c} \frac{\sigma_{y}}{r} d r+\rho_{t}\left(R_{\text {cav }} \ddot{R}_{\text {cav }}+\frac{3}{2} \dot{R}_{\text {cav }}^{2}\right)
$$

右辺第 1 および第 2 項は準静的なキャビティの膨張問題における内圧に対応しており, 第 3 項は慣性の影響を表 している. 式中の $\rho_{t}$ は基材の密度である.また， $\dot{R}_{\mathrm{cav}}$ および $\ddot{\mathrm{c}}_{\mathrm{cav}}$ はキャビティの膨張速度および加速度を表す． 式（15）における右辺第3 項では，実際の球体の衝突問題における慣性の影響を適切に表現寸ることが困難であ る. ここで, $R_{\mathrm{cav}} \ddot{R}_{\mathrm{cav}}$ は $\dot{R}_{\mathrm{cav}}^{2}$ に比べ小さく無視できるため, 慣性の影響を考慮するためにはキャビティの膨張速 度 $\dot{R}_{\mathrm{cav}}$ のみ考慮すればよい. 寸わなち, 実際の球体の衝突問題に置き換えた場合, 球体の基材一の侵入速度 $v$ を 考慮すればよいことになる。ここで，侵入深さ $\delta$ における圧痕表面の法線方向に対する平均速度を $\bar{v}$ とると，

$$
\bar{v}=\left(1-\frac{\delta}{2 R_{p}}\right) v
$$

となる．したがって，球体の衝突問題に対し，式（15）は以下のように簡略化して適用することができる.

$$
p=\frac{2}{3} \sigma_{E}+2 \int_{R_{\mathrm{cav}}}^{c} \frac{\sigma_{y}}{r} d r+\frac{3}{2} k_{1} \rho_{t} \bar{v}^{2}
$$


ここで， $k_{1}$ はキャビティの膨張問題から球体の衝突問題への置き換えに伴う補正係数であり, $k_{1}=0.2$ と求められ ている (Ito and Arai, 2020).

本研究では, 塑性域における降伏応力 $\sigma_{y}$ に対し, 式（1）で表される JC モデルを適用した。 この式を解くため には，塑性域における相当塑性ひずみ，相当塑性ひずみ速度，および温度分布が必要となる．相当塑性ひずみ $\bar{\varepsilon}_{p}$ については，FEAの結果に基づいて，以下の式で近似的に表すことができることを確認している（Ito and Arai， 2020).

$$
\bar{\varepsilon}_{p}=f_{1}\left(\frac{r}{R_{\text {cav }}}\right)^{f_{2}}
$$

ここで， $f_{1}$ および $f_{2}$ は，球体侵入深さ $\delta$ の関数として表される係数および指数である.

$$
\begin{aligned}
& f_{1}=l_{1}\left(\frac{\delta}{R_{p}}\right)^{3}+l_{2}\left(\frac{\delta}{R_{p}}\right)^{2}+l_{3} \frac{\delta}{R_{p}} \\
& f_{2}=l_{4}\left(\frac{\delta}{R_{p}}\right)^{3}+l_{5}\left(\frac{\delta}{R_{p}}\right)^{2}+l_{6} \frac{\delta}{R_{p}}+l_{7}
\end{aligned}
$$

$l_{\mathrm{i}}\left(\mathrm{i}=1 \sim 7 ）\right.$ は材料や条件に依存しない定数であり，FEAの結果に基づいて， $l_{1}=8.7488 ， l_{2}=-11.689, l_{3}=7.0519$, $l_{4}=-8.2255, \quad l_{5}=12.228, \quad l_{6}=-9.1768, l_{7}=-1.8001$ と定められた（Ito and Arai, 2020）.

相当塑性ひずみ速度㐫 球体侵入深さ $\delta$ の関数であることを考慮すると,

$$
\dot{\overline{\varepsilon_{p}}}=\frac{d \overline{\varepsilon_{p}}}{d \delta} \cdot \frac{d \delta}{d t}
$$

となる. 球体侵入深さ $\delta$ の時間微分は，その瞬間における球体の侵入速度 $v$ に致する．ゆえに，

$$
\frac{d \delta}{d t}=v
$$

となる．なお，球体の侵入速度 $v$ は式（9）を数值解析的に解く過程で求められることから，式（21）より相当塑 性ひずみ速度交を算出できる。

基材の塑性変形エネルギーの大部分は熱エネルギーに変換され，その熱エネルギーは塑性域の温度上昇に使わ れる．単位体積当たりの塑性ひずみエネルギー $U_{p}$ は以下の式で表される.

$$
U_{p}=\int \bar{\sigma}_{e} d \bar{\varepsilon}_{p}
$$

ここで， $\bar{\sigma}_{e}$ はミーゼスの相当応力である．ミーゼスの降伏条件に従うものと仮定すると，塑性域において $\bar{\sigma}_{e}$ は式

（1）で表される降伏応力 $\sigma_{y}$ に一致する．断熱変形を仮定した場合，温度変化 $\Delta T$ は以下の式で与えられる.

$$
\Delta T=T-T_{\text {ref }}=\beta \frac{U_{p}}{\rho_{t} c p_{t}}
$$


ここで, $c p_{t}$ は基材の比熱， $\beta$ は変換係数である.なお，本理論では $\beta=0.9$ ，すなわち塑性ひずみエネルギーの $90 \%$ が熱エネルギーに変換されるものと仮定した．以上より，式（18），(21）および（24）を式（1）に代入すること により降伏応力 $\sigma_{y}$ が求まる. さらに, 式（1）を式（17）に代入することにより動的接触圧力 $p$ が算出される.

盛り上がり部半径 $a_{\text {pile }}$ の導出にあたり，図 3 に示寸ような盛り上がりモデルを考える.このモデルでは，元の 基材表面からの盛り上がり部の体積が球体の侵入による排除体積に等しいと仮定する. 図に示寸ように, 盛り上 がり部外縁は圧痕半径 $a$ に比例するものとし, その比例定数を $k_{2}$ とする. なお, FEA の結果から, $k_{2}=2.4$ と定 められた（Ito and Arai, 2020）。また，盛り上がり部頂上と外縁を結ぶ稜線は線形とする. 図の斜線部で示してい る圧痕の体積 $V_{1}$ は幾何的に求めることができ, 以下のように表される.

$$
V_{1}=\pi\left(R_{p} \delta^{2}-\frac{1}{3} \delta^{3}\right)
$$

図の濃い灰色で示している盛り上がり部の体積 $V_{2}$ は，前述の仮定より，以下のように表される.

$$
V_{2}=2 \pi \int_{a}^{a_{\mathrm{pile}}}\left(\sqrt{R_{p}^{2}-a^{2}}-\sqrt{R_{p}^{2}-x^{2}}\right) x d x+\frac{\pi}{3} h\left(k_{2}^{2} a^{2}+k_{2} a a_{\mathrm{pile}}-2 a_{\mathrm{pile}}^{2}\right)
$$

式中の $x$ は, 図 3 に示寸ように圧痕中心から水平方向の座標として定義している. 図圧痕の体積 $V_{1}$ には, 実際に は塑性変形のみならず弾性変形の影響も含まれる，圧痕が大きい場合には弹性変形は塑性変形に比べ無視できる ほど小さいが，圧痕が小さい場合には弾性変形の影響を考慮しなければならない，そこで，図の薄い灰色で示し ている圧痕の弾性変形体積 $V_{3}$ を考える. まず，圧痕表面の面積 $S_{\text {int }}$ は，

$$
S_{\text {int }}=2 \pi R_{p} \delta
$$

となる. また, 図 2 のキャビティモデルにおいて, 内圧 $p$ を受ける無限体中の半径方向の弾性変位 $u(r)$ は,

$$
u(r)=\left(\frac{r}{E_{t}}\right)\left\{\left(1-v_{t}\right) \sigma_{\theta}-v_{t} \sigma_{r}\right\}=\frac{\left(1+v_{t}\right) p R_{\mathrm{cav}}^{3}}{2 E_{t} r^{2}}
$$

と求められる. 式 (28) を球体の衝突問題へ適用するにあたり， $R_{\mathrm{cav}}$ を $R_{p}$ と仮定すると，圧痕表面の弾性変形変 位 $\delta_{\text {rec }}$,

$$
\delta_{\text {rec }}=\frac{\left(1+v_{t}\right) p R_{p}}{2 E_{t}}
$$

と求まる. 式（27）および（29）より，V、は以下のように表される.

$$
V_{3}=S_{\text {int }} \cdot \delta_{\text {rec }}=\frac{\pi\left(1+v_{t}\right) p R_{p}^{3} \delta}{E_{t}}
$$

盛り上がり部の体積が球体の侵入による排除体積に等しいと仮定すると，

$$
V_{1}-V_{3}=V_{2}
$$

が成り立つ. 式（31）を解くことで盛り上がり部半径 $a_{\text {pile }}$ を求めることができる. 
以上より，式（1）に基づいて算出される動的接触圧力 $p$ と式（31）に基づいて算出される盛り上がり部半径 $a_{\text {pile }}$ を用いることにより, 式（9）を解くことができる．圧痕寸法予測理論では，基材の JCパラメータである $A$, $B, C, m$ および $n$ が全て既知の場合を想定している. このとき, 式 (9) より球体の最大侵入深さ $\delta_{\max }$ が算出さ れる. 図 1 (c) に示したように, 衝突後に測定される実際の圧痕深さ $\delta_{\text {act }}$ は弾性回復の影響を考慮する必要があ る.すなわち,

$$
\delta_{\mathrm{act}}=\delta_{\max }-\delta_{\mathrm{rec}}=\delta_{\max }-\frac{\left(1+v_{t}\right) p R_{p}}{2 E_{t}}
$$

となる. 本式より圧痕深さ $\delta_{\text {act }}$ を予測することができる.

一方，本研究で提案する EJCC 法では，JCパラメータのうちCのみが未知の場合を想定する. ここで, 球体高 速衝突試験を行うことにより圧痕深さ $\delta_{\text {act }}$ を測定する. この場合, 以下の式より最大侵入深さ $\delta_{\max }$ が算出される.

$$
\delta_{\max }=\delta_{\mathrm{act}}+\frac{\left(1+v_{t}\right) p R_{p}}{2 E_{t}}
$$

本式を式（9）に代入することにより，基材の JC パラメータ $C$ を推定することができる.

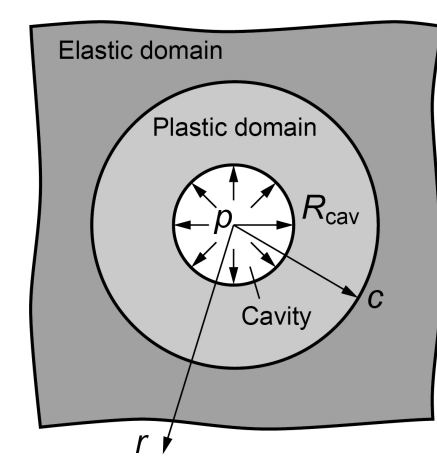

Fig. 2 Cavity model subjected to inner pressure $p$ in an elasto-plastic infinite media.

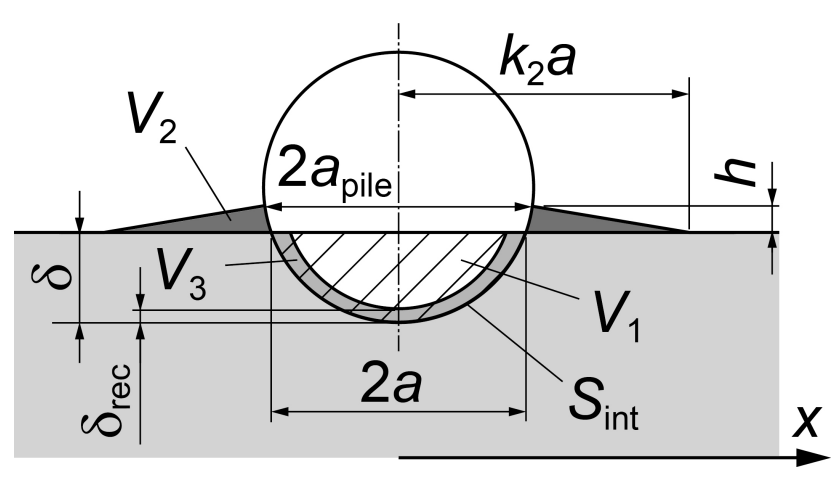

Fig. 3 Schematic of the pile-up model.

\section{$2 \cdot 2$ 有限要素解析に基づく EJCC 法の妥当性検証}

EJCC 法の妥当性を検証するために, FEA による球体の衝突解析を行った。 FEA には汎用有限要素解析コード Marc（Ver. 2010，MSC Software）を用いた．解析モデルを図 4 に示す. 図のような軸対称モデルを作成した。基 材は $\phi 36 \mathrm{~mm} \times 27 \mathrm{~mm}$ の円柱形状とし, 球体半径 $R_{p}$ を $2.25 \mathrm{~mm}$ とした. 図のように, 解析モデルの下端面の $x$ 軸 方向変位を拘束し, 基材右端面の $z$ 軸方向変位を拘束した. 基材の要素分割に際しては, 球体との接触点近傍は 他領域より細かくなるようにした。 なお，最小メッシュサイズは $0.0375 \mathrm{~mm}$ とした. また，球体との接触点近傍 において基材の変形が大きくなることから, Marc の GLOBAL REMASHING 機能を適用し, 1 インクリメントご とにリメッシュを行った.リメッシュの適用領域と周辺の領域との結合にはGLUE機能を用いた. 球体は弾性体, 基材は弾塑性体とし, 弾性変形に対しては一般的なフックの法則に従うものとした. 基材の加工硬化モデルには JCモデルを用いた。また，球体は高炭素クロム軸受鋼（SUJ2）を想定し，基材についてはC1020および SUS304 の 2 つの材料について解析を行った．解析に用いた各材料の物性值および JCパラメータを表 1 に示す. JCパラ メータには文献值を用いた（Assadi et al., 2003）（Zhang et al., 2011）。なお，球体と基材との接触界面の摩擦係数は 0 とした. 衝突速度は 100，150，200，250，300 m/s の 5 条件として解析を行った.

衝突後の圧痕深さ $\delta_{\text {act }}$ を評価し, EJCC 法に代入することで推定される JC パラメータ $C$ と解析に用いた JC パ ラメータ $C$ を比較した. 図 5 に, 各基材における衝突速度と $\mathrm{JC}$ パラメータ $C$ の関係を示す. 図から, 基材およ 
び衝突速度によらずEJCC 法により推定された $C$ と解析に用いた $C$ は概ね一致していることがわかる.このこと から, EJCC 法の妥当性が確認された。

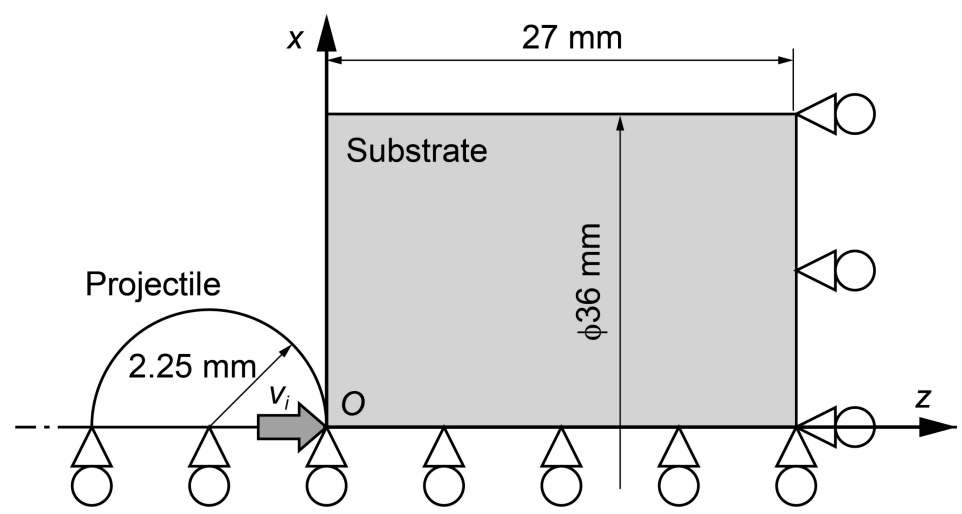

Fig. 4 Schematic of the axisymmetric model for the FEA.

Table 1 Material constants and JC parameters used for the FEA.

\begin{tabular}{|c|c|c|c|c|c|c|c|c|c|c|c|}
\hline & $\begin{array}{c}\rho \\
{\left[\mathrm{kg} / \mathrm{m}^{3}\right]}\end{array}$ & $\begin{array}{c}E \\
{[\mathrm{GPa}]}\end{array}$ & $\begin{array}{c}v \\
{[-]}\end{array}$ & $\begin{array}{c}T_{m} \\
{[\mathrm{~K}]}\end{array}$ & $\begin{array}{c}c p \\
{[\mathrm{~J} / \mathrm{kg} \cdot \mathrm{K}]}\end{array}$ & $\begin{array}{c}A \\
{[\mathrm{MPa}]}\end{array}$ & $\begin{array}{c}B \\
{[\mathrm{MPa}]}\end{array}$ & $\begin{array}{c}C \\
{[-]}\end{array}$ & $\begin{array}{c}m \\
{[-]}\end{array}$ & $\begin{array}{c}n \\
{[-]}\end{array}$ & $\begin{array}{c}\dot{\varepsilon}_{0} \\
{\left[\mathrm{~s}^{-1}\right]}\end{array}$ \\
\hline SUJ2 & 7850 & 207 & 0.3 & - & - & - & - & - & - & - & - \\
\hline C1020 & 8940 & 112 & 0.33 & 1356 & 383 & 77.9 & 253 & 0.026 & 0.31 & 1.09 & 0.002 \\
\hline SUS304 & 7930 & 193 & 0.3 & 1673 & 590 & 175 & 565 & 0.07 & 0.65 & 1.0 & 0.002 \\
\hline
\end{tabular}

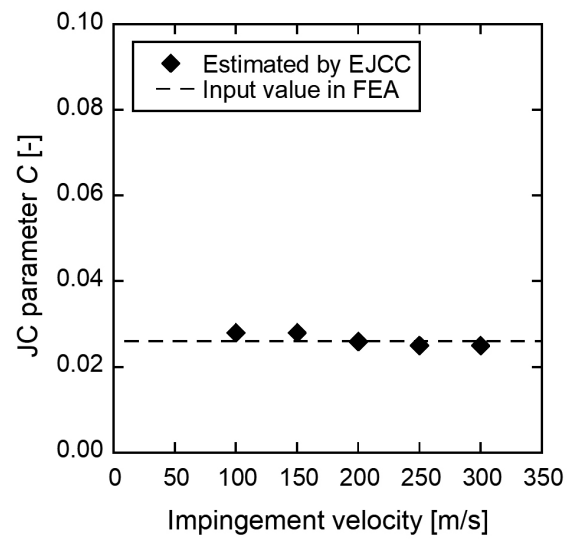

(a) $\mathrm{C} 1020$

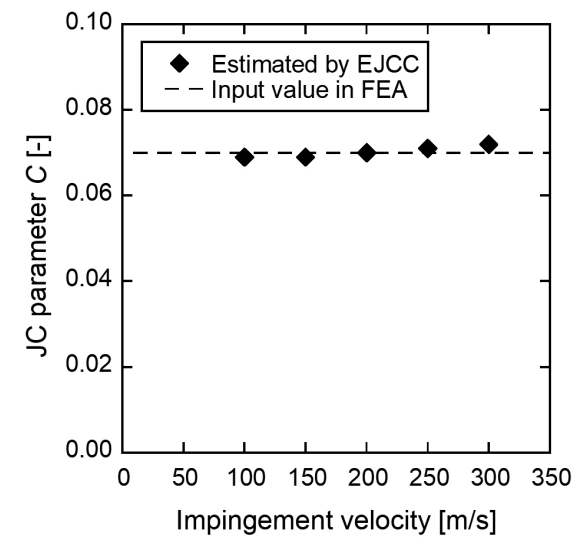

(b) SUS304

Fig. 5 Relationship between impingement velocity and JC parameter $C$ estimated by the EJCC. The estimated values are in good agreement with the input value of the FEA. These results show the validity of the EJCC.

\section{3. 準静的および高速引張試験による JC パラメータの同定}

\section{$3 \cdot 1$ 供試材および試験方法}

供試材として，C1020，SUS304 およびS15C の 3 種類の延性金属材料を用いた．準静的引張試験および高速引 張試験に用いた試験片形状を図 6 に示寸. 各試験片を $\phi 25 \mathrm{~mm}$ の同一焼鈍丸棒材から機械加工により切り出した. 準静的引張試験片については丸棒形状とし, 高速引張試験片については平板形状とした. 試験片平行部の表面に ついては，耐水研磨紙（リファインテック株式会社）により\#800まで研磨した．各材料について，それぞれ2本 ずつ試験片を準備した。 
準静的引張試験には島津製作所（株）製のサーボパルサー（EHF-EB50KN-20L，最大負荷容量 $50 \mathrm{kN}$ ，最大ス卜 ローク $\pm 25 \mathrm{~mm}$ ）を用いた. 試験は変位制御のもと，ひずみ速度 $0.002 \mathrm{~s}^{-1}$ として室温大気環境下で行った. 試験中 の荷重をロードセル（SFL-50kN，島津製作所）により測定し，試験片平行部に生じるひずみをひずみゲージによ り測定した. 本試験では, JCパラメータ $A, B, n$ を適切に評価するために, 比較的大きなひずみまで応力一ひず み線図を取得する必要がある，そのため，大ひずみ測定用のひずみゲージ（KFEM-5-120-C1L1M2R，共和電業） を用いた，一方，本ひずみゲージでは弾性域のひずみ測定が困難であることから，一般的なひずみ測定用のひず みゲージ（KFGS-2-120-C1-11 L1M2R，共和電業）も併用した．両ひずみゲージより得られる電気信号を，動ひず み測定器 (DPM-711B, DPM-913B, 共和電業) を介してサンプリング周期 $0.1 \mathrm{~s}$ でデータロガー (GL220, GRAPHTEC) に取り込んだ.

高速引張試験には油圧サーボ式高速引張試験機 HITS-TX（島津製作所，最大衝撃試験力 $10 \mathrm{kN}$ ，最大速度 20 $\mathrm{m} / \mathrm{s}$ ，最大ピストン移動量 $300 \mathrm{~mm}$ ）を用いた．試験は変位制御のもと，目標ひずみ速度 $100 \mathrm{~s}^{-1}$ として室温大気環 境下で行った. 試験中の荷重をロードセル（SHL-10kN，島津製作所）により測定し，試験片平行部に生じるひず みをひずみゲージ (KFGS-1N-120-C1-11，共和電業）により測定した. ひずみゲージより得られる電気信号を，動 ひずみ測定器（DC-97A，東京測器研究所）を介してサンプリング周期 $1 \mu \mathrm{s}$ でデータロガーに取り込んだ.

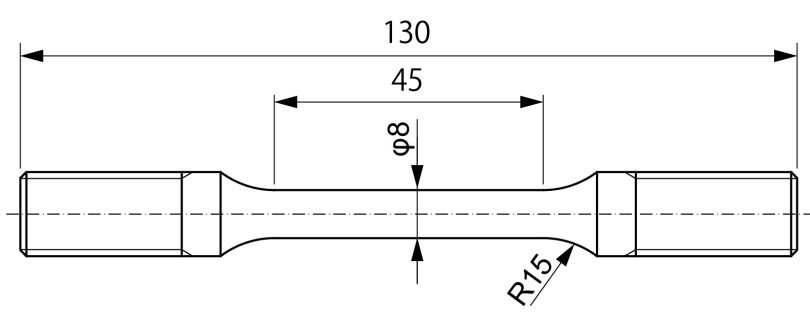

(a) For quasi-static tensile test

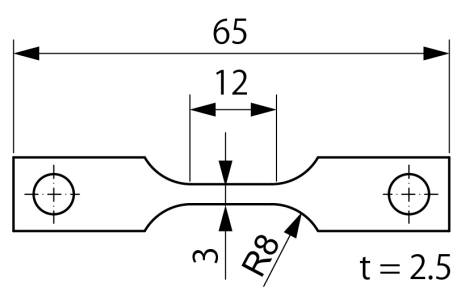

(b) For high-speed tensile test

Fig. 6 Geometry of specimens for the quasi-static tensile test and the high-speed tensile test (unit: $\mathrm{mm}$ ).

\section{$3 \cdot 2 \mathrm{JC}$ パラメータの同定}

準静的引張試験によって得られた各材料の真応力一真ひずみ線図（以降，単に応力ーひずみ線図と記す）を図 7 に示す. なお，横軸は大ひずみ測定用のひずみゲージによるひずみであり，ひずみが 0.1 まで示している. 図よ り, C1020 および SUS304 については, 弾性変形後, ひずみの増加に伴い応力が緩やかに増加する加工硬化が認 められる. $\mathrm{S} 15 \mathrm{C}$ にいては, 上降伏点到達後, 一端下降伏点まで応力が低下し，一定状態を維持した後，上昇に 転じている．これは，炭素鋼特有の現象であり，炭素原子による転位の固着と解放に起因している．準静的引張 試験によって得られた結果に基づいて，JCパラメータ $A, B, n$ を同定した.まず，一般的なひずみ測定用のひず みゲージによる応力ーひずみ線図から, 各材料の縦弾性係数 $E$ および $0.2 \%$ 耐力を算出し, $0.2 \%$ 耐力を $\mathrm{JC}$ パラメ 一タ $A$ とした。 なお， $\mathrm{S} 15 \mathrm{C}$ については下降伏点を $\mathrm{JC}$ パラメータ $A$ として採用した。 また， JCパラメータ $B$ お よび $n$ については，図 7 に示した応力ーひずタ線図に基づいて同定した．本試験のひずみ速度 $0.002 \mathrm{~s}^{-1}$ を参照ひ ずみ速度 $\dot{\varepsilon}_{0}$ とすると, 式（1）の JC モデルにおいて第 2 項は消去される. 同様に, 室温を参照温度 $T_{\mathrm{ref}}$ とすると 第 3 項は消去される. その結果, JC モデルは以下のように簡略化される.

$$
\sigma_{y}=A+B \bar{\varepsilon}_{p}^{n}
$$

となる．この式を変形し，両辺対数をとると以下のようになる．

$$
\log \left(\sigma_{y}-A\right)=\log B+n \log \bar{\varepsilon}_{p}
$$

式（30）より，縦軸に対数化した $\sigma_{y}-A$, 横軸に対数化した塑性ひずみをとったグラフを作成し, その近似直線の 傾きから $n$ が, 切片から $B$ が求まる. なお，このようにして求められた $A, B, n$ を式（29）に代入することで得 られる応力ーひずみ線図と実験結果に明確なずれが生じた場合, 実験結果と一致するようにこれらのパラメータ 
を修正した．表 2 に，準静的引張試験によって同定された縦弾性係数および各 JC パラメータを示す．これらの パラメータを式（29）に代入することで得られる応力ーひずみ線図を図７に青線で示している．なお，真応力が $A$ に達するまでは，測定された縦弾性係数に従って弾性変形するものとしている．図から，実験によって得られ

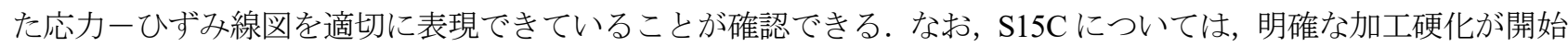
するひずみまで $\sigma_{y}$ は $A$ で一定とした。

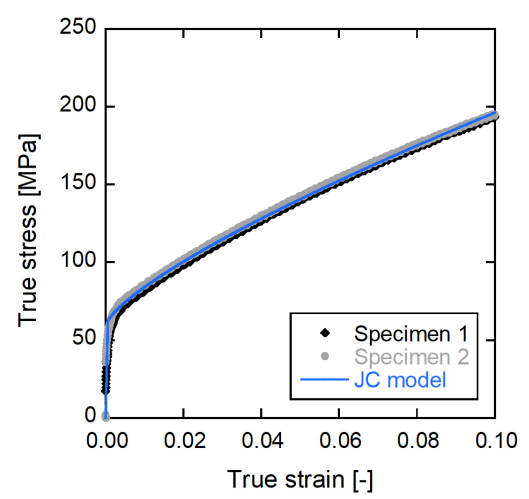

(a) $\mathrm{C} 1020$

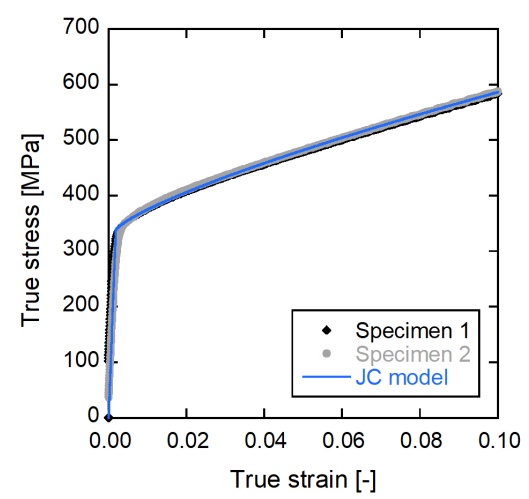

(b) SUS304

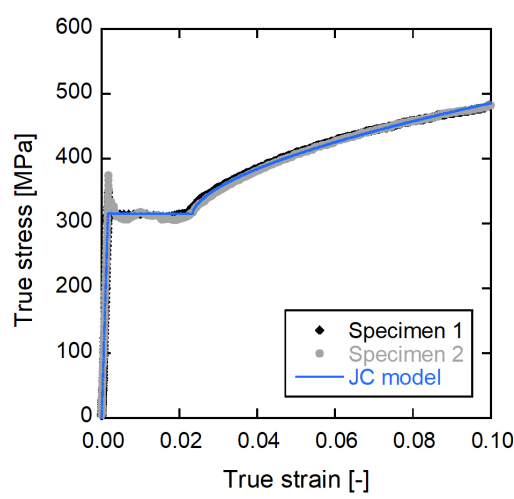

(c) $\mathrm{S} 15 \mathrm{C}$

Fig. 7 True stress - true strain curves obtained by the quasi-static tensile test for each material. These curves can be accurately expressed by the JC model given as Equation (29) with the JC parameters determined from these curves.

Table 2 Young's modulus and JC parameters determined by the quasi-static tensile test.

\begin{tabular}{|c|c|c|c|c|}
\hline & $E[\mathrm{GPa}]$ & $A[\mathrm{MPa}]$ & $B[\mathrm{MPa}]$ & $n[-]$ \\
\hline C1020 & 114 & 62 & 784 & 0.765 \\
\hline SUS304 & 188 & 338 & 1466 & 0.765 \\
\hline S15C & 196 & 315 & 777 & 0.59 \\
\hline
\end{tabular}

高速引張試験によって得られた各材料の真応力一真ひずみ線図を図 8 に示す. SUS304 を例にとると，前述の 準静的引張試験における応力一ひずみ線図と同様の挙動を示しているが，降伏応力が顕著に上昇していることが わかる. 得られた結果から，0.2\%耐力および塑性ひずみ速度を算出した．準静的引張試験における $0.2 \%$ 耐力と塑

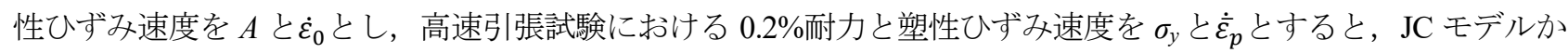
ら以下の関係が成り立つ.

$$
\sigma_{y}=A\left(1+C \ln \frac{\dot{\bar{\varepsilon}}_{p}}{\dot{\varepsilon}_{0}}\right)
$$

式（31）をCについて変形すると，

$$
C=\frac{\left(\frac{\sigma_{y}}{A}-1\right)}{\ln \frac{\dot{\bar{\varepsilon}}}{\dot{\dot{\varepsilon}_{0}}}}
$$

となり，本式より $C$ を求めることができる.

表 3 に各材料の JC パラメータ C をまとめる. ただし, S15C については図 8 (c) に示したように, 下降伏点 の変動が大きいことが確認されている，そのため，準静的引張試験および高速引張試験ともに上降伏点の值に基 
づいて $C$ を決定した，各材料について，準静的引張試験と高速引張試験結果の組み合せにより 4 通りの $C$ が算 出される．表には算出された $C$ の最大值，最小值およびその平均值を示してある.

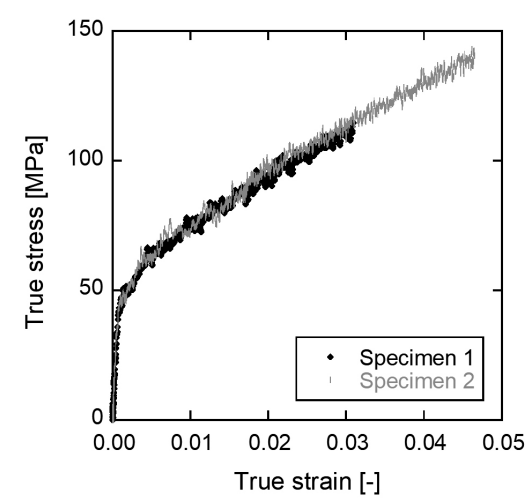

(a) $\mathrm{C} 1020$

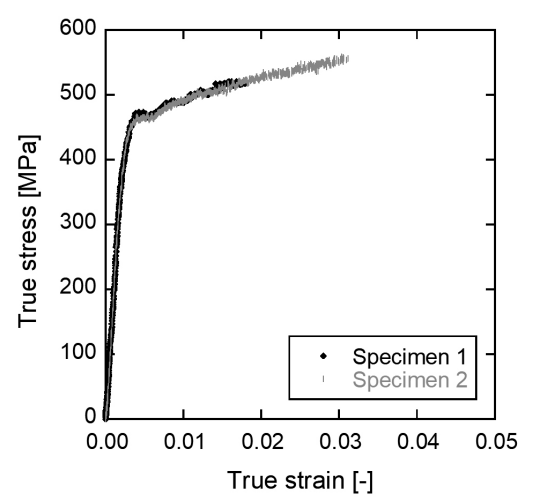

(b) SUS304

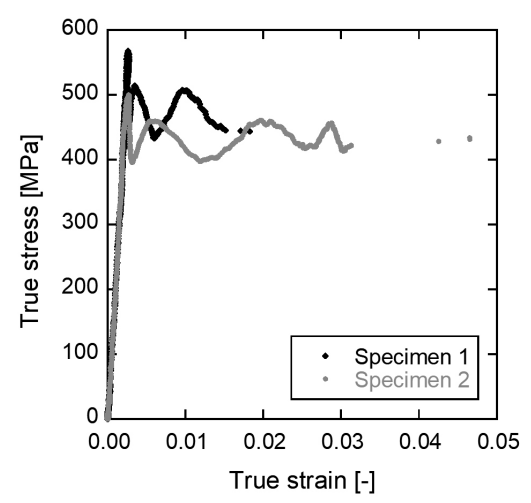

(c) $\mathrm{S} 15 \mathrm{C}$

Fig. 8 True stress - true strain curves obtained by the high-speed tensile test for each material. $0.2 \%$ proof stress was evaluated from these curves for the evaluation of JC parameter $C$. In the case of S15C, the upper yield point was employed instead of $0.2 \%$ proof stress.

Table 3 JC parameter $C$ determined by the high-speed tensile test.

\begin{tabular}{|c|c|c|c|}
\hline \multirow{2}{*}{} & \multicolumn{3}{|c|}{ JC parameter $C[-]$} \\
\cline { 2 - 4 } & Maximum & Minimum & Average \\
\hline C1020 & -0.0064 & -0.0166 & -0.0115 \\
\hline SUS304 & 0.0409 & 0.0345 & 0.0377 \\
\hline S15C & 0.0591 & 0.0329 & 0.0478 \\
\hline
\end{tabular}

\section{4. 球体高速衝突試験に基づくひずみ速度依存性評価}

\section{$4 \cdot 1$ 供試材および試験方法}

供試材には前述の C1020，SUS304 および S15C を用いた。引張試験に用いたものと同じ焼針丸棒材から $\phi 24.5$ $\mathrm{mm} \times 25 \mathrm{~mm}$ の円柱形状試験片を旋盤加工により削り出した．その後，研削加工により表面を仕上げた．球体高 速衝突試験には，自作の球体高速衝突試験装置を用いた。球体高速衝突試験の概略図を図 9 に示す。本装置は, 窒素またはへリウムの圧縮ガスにより球体をステンレスパイプ内で加速させ，減圧チャンバー内に設置した試験 片表面に衝突させる機構となっている，圧縮ガスの種類または圧力を変更することで衝突速度を任意に制御可能 となっている．また，減圧チャンバー内を減圧することで空気抵抗を減らし，より高速度での衝突を実現してい る. 衝突速度の測定には連続発振半導体レーザー（LDU33，シグマ光機株式会社）を用い，2 本のレーザーが球

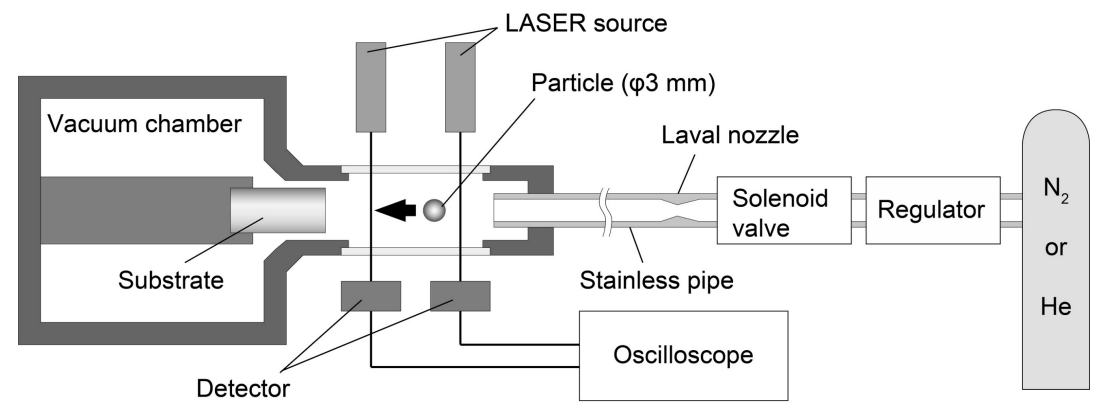

Fig. 9 Schematic illustration of single particle impact testing system. 
体により遮られる時間差から衝突速度を算出する．なお，レーザー距離は $60 \mathrm{~mm}$ となっている. 球体には $\phi 4.5$ $\mathrm{mm}$ の SUJ2 鋼球（大橋鋼球）を用い, 衝突速度を $50 \sim 350 \mathrm{~m} / \mathrm{s}$ の範囲で試験を行った. 衝突試験後, 試験片表面 の圧痕深さ $\delta_{\mathrm{act}}$ を 3 次元形状測定器（VR-3050, 株式会社キーエンス）により測定した.

\section{4・2 EJCC 法による JC パラメータ Cの推定結果}

球体高速衝突試験後の試験片表面の外観写真を図 10 に示寸. 写真から，いずれの材料についても基材表面には 半球状の圧痕が形成されていることがわかる，また，圧痕周辺では基材表面にしわが認められ，盛り上がりが生 じている様子が確認できる. 図 11 に, 各基材における衝突速度と圧痕深さの関係を示寸. なお, 圧痕深さは球体 半径 $R_{p}$ で除すことにより無次元化してある. 図から, いずれの基材についても, 衝突速度の増加に伴い圧痕深さ が概ね線形的に増加している．また，材料によって圧痕深さは大きく異なっていることが確認できる.

以上の圧痕深さの測定結果に基づいて, EJCC 法により各材料の JC パラメータ $C$ を推定した。 なお， JC パラ メータ $A, B, n$ については, 前述の準静的引張試験から得られた值の平均值を用いた。 また, $m$ については文献 值を用いた（Assadi et al., 2003）（Zhang et al., 2011）（Buchely et al., 2019）。各基材における衝突速度とJCパラメー タ $C$ の関係を図 12 に示寸. 図中の 2 本の直線は, それぞれ高速引張試験によって測定された JCパラメータ $C$ の 最大值と最小值を示している. Tabor が提案している押込夕問題における等価塑性ひずみに基づくと, 球体高速 衝突試験によるひずみ速度は $10^{4} \sim 10^{6}$ の範囲と概算される（Tabor, 1951）。したがって, 高速引張試験におけるひ ずみ速度とは顕著に異なる。しかしながら, 既存の試験法ではこのような高ひずみ速度を得るのは困難である. また, 図 11 に示した圧痕深さの傾向から JC パラメータ $C$ 自体のひずみ速度依存性は小さいものと推定される. これらのことから, 本研究では高速引張試験による試験結果との比較を行っている. 図から, SUS304 および S $15 \mathrm{C}$ の低速度領域で顕著な誤差が認められるものの, 高速引張試験の最大值と最小值の間の範囲に EJCC 法による推 定值が概㸚収まっていることがわかる.このことから，一般的な延性金属材料について，EJCC 法により従来の油 圧サーボ法と概ね同等の精度で JC パラメータ $C$ を推定できることが確認された. C1020 の結果に注目すると， 衝突速度に伴い $C$ の推定值は右肩上がりの傾向を有している，一方， $\mathrm{S} 15 \mathrm{C}$ では，右肩下がりの傾向を示してい る. これらの誤差や傾向の違いは, ECC 法の理論の不完全さ, 実験における測定誤差, 材料のばらつきなどに起 因している. 特に, 図 3 に示した盛り上がりモデルについて, 本モデルでは材料によらず盛り上り形状は一定と 仮定している.一方, FEAによる結果では, 材料によって盛り上り形状は顕著に異なることが確認されている (Ito and Arai, 2020)．より高精度に JC パラメータ $C$ を推定するためには, 今後さらなる理論の改善を進めていく必要 がある。

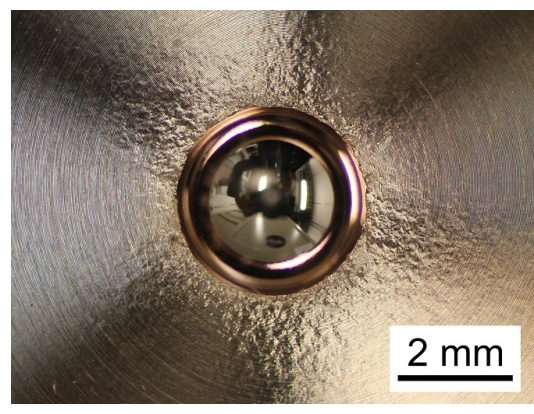

(a) C1020 impinged at $228 \mathrm{~m} / \mathrm{s}$

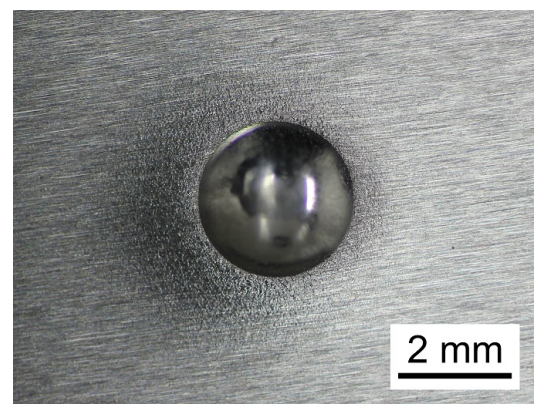

(b) SUS304 impinged at $240 \mathrm{~m} / \mathrm{s}$

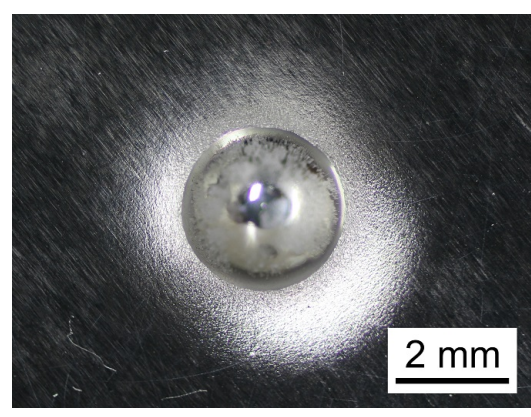

(c) S15C impinged at $227 \mathrm{~m} / \mathrm{s}$

Fig. 10 Appearance of indentation on each substrate material formed by an impingement of a SUJ2 ball. A hemispherical indentation is formed on the surface. 


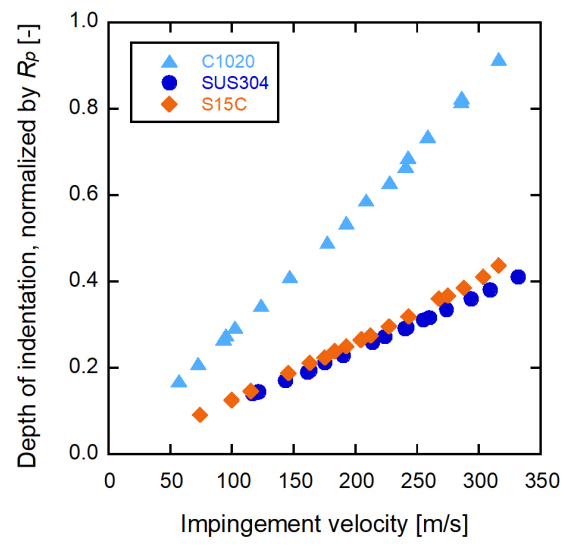

Fig. 11 Relationship between impingement velocity and depth of indentation normalized by $R_{p}$. The depth of indentation increases almost linearly with increasing impingement velocity irrespective of the substrate material. In addition, the depth of indentation at the same impingement velocity depends on the substrate material.

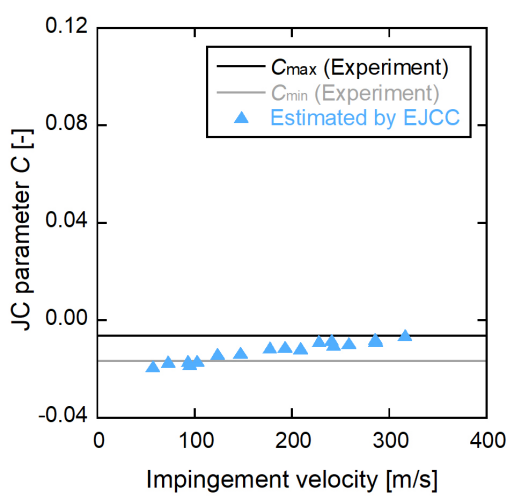

(a) $\mathrm{C} 1020$

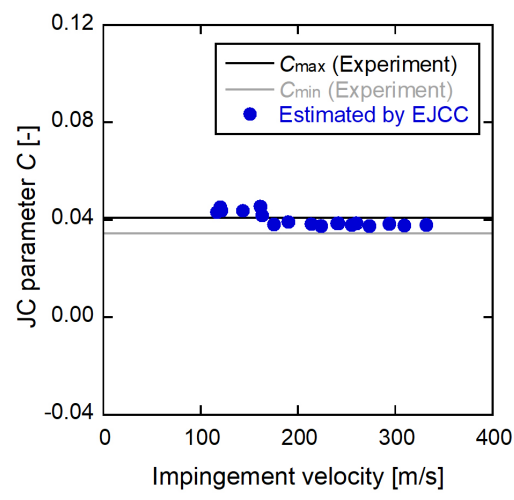

(b) SUS304

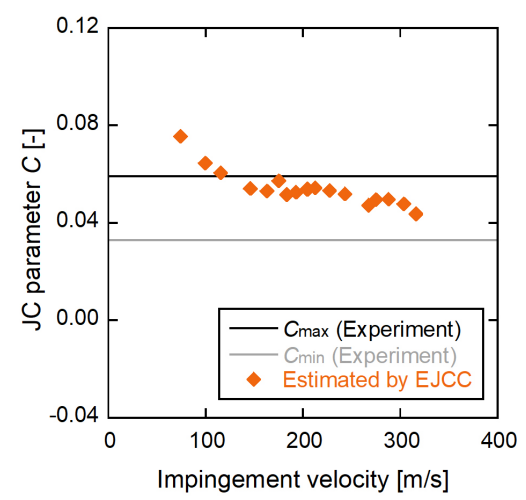

(c) $\mathrm{S} 15 \mathrm{C}$

Fig. 12 JC parameter $C$ of each material estimated by the EJCC at several impingement velocities. The almost estimated values are within the range of $C$ evaluated by the experiment. These results demonstrate the effectiveness of the EJCC for ductile metallic materials.

\section{5. 結 言}

本研究では, 球体高速衝突試験により基材表面に形成された圧痕深さに基づいて，材料のひずみ速度依存性を 表す Johnson-Cook（JC）パラメータ C を推定する EJCC 法を開発した. 純銅 $(\mathrm{C} 1020)$, 低炭素鋼 $(\mathrm{S} 15 \mathrm{C})$, オー ステナイト系ステンレス鋼（SUS304）の3つの延性金属材料に対して準静的引張試験および球体高速衝突試験を 行い, 得られた JCパラメータ $A, B, n$ と圧痕深さから EJCC 法により JCパラメータ $C$ の推定を試みた.また, 高速引張試験により得られた JC パラメータ $C$ と本手法により推定された $C$ を比較することにより，本手法の有 効性を検証した. その結果, 高速引張試験により得られた JC パラメータ $C$ の最大值と最小值の間の範囲に EJCC 法による推定值が概ね収まっていることが確認された。このことから，一般的な延性金属材料について，EJCC 法 により適切に JCパラメータ $C$ を推定できることが示された.

\section{謝辞}

本研究は，JSPS科研費JP19K14846の支援を受けたものであり，ここに記して謝意を表する．また，高速引張試 験は（株）島津テクノリサーチにて実施頂いた。関係者にはここに感謝する. 


\section{文献}

Assadi, H., Gärtner, F., Stoltenhoff, T. and Kreye, H., Bonding mechanism in cold gas spraying, Acta Materialia, Vol.51, No.15 (2003), pp.4379-4394.

Bäker, M., A new method to determine material parameters from machining simulations using inverse identification, Procedia CIRP, Vol.31 (2015), pp.399-404.

Buchely, M. F., Wang, X., Van Aken, D. C., O'Malley, R. J., Lekakh, S. and Chandrashekhara, K., The use of genetic algorithms to calibrate Johnson-Cook strength and failure parameters of AISI/SAE 1018 steel, Journal of Engineering Materials and Technology, Vol.141, No.2 (2019), 021012.

Burley, M., Campbell, J., Dean, J. and Clyne, B., Johnson-Cook parameter evaluation from ballistic impact data via iterative FEM modelling, International Journal of Impact Engineering, Vol.112 (2018), pp.180-192.

Cowper, G. R. and Symonds, P. S., Strain hardening and strain rate effects in the impact loading of cantilever beams, Division of Applied Mathematics, Brown University (1957).

Grazka, M. and Janiszewski, J., Identification of Johnson-Cook equation constants using finite element method, Engineering Transactions, Vol.60, No.3 (2012), pp. 215-223.

Hill, R., The mathematical theory of plasticity, Oxford University Press, University of Oxford, UK (1950).

Hopkins, H.G., Progress in solid mechanics Vol. 1, North-Holland Publishing Co., Amsterdam, Netherlands (1960).

Ito, K. and Arai, M., Expanding cavity model combined with Johnson-Cook constitutive equation for the dynamic indentation problem, Journal of Engineering Materials and Technology, Vol.142, No.2 (2020), 021005.

Johnson, G. R. and Cook, W. H., A constitutive model and data for metals subjected to large strains, high temperatures, Proceedings of the 7th International Symposium on Ballistics, Hague, Netherlands (1983), pp. 541-548.

Johnson, K. L., Contact Mechanics, Cambridge University Press, University of Cambridge, UK (1985).

三村耕司, 平田晋, 中馬義孝, 谷村眞治, 検力ブロックを利用した動的負荷試験装置の開発とその応力一ひずみ曲 線評価への応用，日本機械学会論文集 A 編, Vol.62, No.603 (1996), pp.2609-2614.

三浦和哉，高木周作，古君修，谷村眞治，鋼板強度の結晶粒径依存性に及ぼすひずみ速度の影響，材料，Vol.47， No.10 (1998), pp.1053-1058.

小川欽也，スプリット・ホプキンソン棒法の最近の進歩, 実験力学, Vol.2, No.2 (2002), pp.89-96.

小野仁幹, 影山雄介, 井山淳, 原聡, ルディーレイモンド, 井手剛, 衝突シミュレーションのデータマイニングに よる衝突性能予測と知識発見，自動車技術会論文集, Vol.47, No.4 (2016), pp.913-918.

Tabor, D., The hardness of metals, Oxford University Press, University of Oxford, UK (1951).

高木周作，高速引張試験機のラウンドロビンテスト結果と材料研究への展開，材料, Vol.60, No.3 (2011), pp.265-272. 谷村眞治, 材料の高速変形と構成式, 日本金属学会会報, Vol.29, No.5 (1990), pp.337-344.

Wahab, N., Sasahara, H., Baba, S., Hiratsuka, Y. and Nakamura, T., Development of high-speed shearing method to obtain flow stress under high strain rate, International Journal of Modeling and Optimization, Vol.5, No.2 (2015), pp.140-144.

Zhang, X.C., Lu, J. and Shi, S.Q., A computational study of plastic deformation in AISI 304 induced by surface mechanical attrition treatment, Mechanics of Advanced Materials and Structures, Vol.18, No.8 (2011), pp.572-577.

\section{References}

Assadi, H., Gärtner, F., Stoltenhoff, T. and Kreye, H., Bonding mechanism in cold gas spraying, Acta Materialia, Vol.51, No.15 (2003), pp.4379-4394.

Bäker, M., A new method to determine material parameters from machining simulations using inverse identification, Procedia CIRP, Vol.31 (2015), pp.399-404.

Buchely, M. F., Wang, X., Van Aken, D. C., O'Malley, R. J., Lekakh, S. and Chandrashekhara, K., The use of genetic algorithms to calibrate Johnson-Cook strength and failure parameters of AISI/SAE 1018 steel, Journal of Engineering Materials and Technology, Vol.141, No.2 (2019), 021012. 
Burley, M., Campbell, J., Dean, J. and Clyne, B., Johnson-Cook parameter evaluation from ballistic impact data via iterative FEM modelling, International Journal of Impact Engineering, Vol.112 (2018), pp.180-192.

Cowper, G. R. and Symonds, P. S., Strain hardening and strain rate effects in the impact loading of cantilever beams, Division of Applied Mathematics, Brown University (1957).

Grazka, M. and Janiszewski, J., Identification of Johnson-Cook equation constants using finite element method, Engineering Transactions, Vol.60, No.3 (2012), pp. 215-223.

Hill, R., The mathematical theory of plasticity, Oxford University Press, University of Oxford, UK (1950).

Hopkins, H.G., Progress in solid mechanics Vol. 1, North-Holland Publishing Co., Amsterdam, Netherlands (1960).

Ito, K. and Arai, M., Expanding cavity model combined with Johnson-Cook constitutive equation for the dynamic indentation problem, Journal of Engineering Materials and Technology, Vol.142, No.2 (2020), 021005.

Johnson, G. R. and Cook, W. H., A constitutive model and data for metals subjected to large strains, high temperatures, Proceedings of the 7th International Symposium on Ballistics, Hague, Netherlands (1983), pp. 541-548.

Johnson, K. L., Contact Mechanics, Cambridge University Press, University of Cambridge, UK (1985).

Mimura, K., Hirata, S., Chuman, Y. and Tanimura, S., Development of a compact dynamic loading device with a stress sensing block and its application to the evaluation of stress-strain relations at high rates of strain, Transactions of the Japan Society of Mechanical Engineers, Series A, Vol.62, No.603 (1996), pp.2609-2614 (in Japanese).

Miura, K., Takagi, S., Furukimi, O. and Tanimura, S., Influence of strain rate on grain size dependence of strength of sheet steel, Journal of the Society of Materials Science, Japan, Vol.47, No.10 (1998), pp.1053-1058 (in Japanese).

Ogawa, K., Recent developments on the split Hopkinson pressure bar method, Journal of the Japanese Society for Experimental Mechanics, Vol.2, No.2 (2002), pp.89-96 (in Japanese).

Ono, M., Kageyama, Y., Iyama, J., Hara, S., Rudy, R. and Ide, T., Crash performance prediction and knowledge discovery from crash simulation using data mining, Transactions of Society of Automotive Engineers of Japan, Vol.47, No.4 (2016), pp.913-918 (in Japanese).

Tabor, D., The hardness of metals, Oxford University Press, University of Oxford, UK (1951).

Takagi, S., Round robin test results of high strain rate tensile test machines and an advanced application to study of high strain rate deformation behavior of materials, Journal of the Society of Materials Science, Japan, Vol.60, No.3 (2011), pp.265272 (in Japanese).

Tanimura, S., Dynamic behavior of materials and the constitutive equations, Bulletin of the Japan Institute of Metals, Vol.29, No.5 (1990), pp.337-344 (in Japanese).

Wahab, N., Sasahara, H., Baba, S., Hiratsuka, Y. and Nakamura, T., Development of high-speed shearing method to obtain flow stress under high strain rate, International Journal of Modeling and Optimization, Vol.5, No.2 (2015), pp.140-144.

Zhang, X.C., Lu, J. and Shi, S.Q., A computational study of plastic deformation in AISI 304 induced by surface mechanical attrition treatment, Mechanics of Advanced Materials and Structures, Vol.18, No.8 (2011), pp.572-577. 